\title{
Postural control of size of the feet of children in school age
}

\author{
Daniela Fernanda Esteves De Andrade(1), Jessica Caroliny De Jesus Neves (1), Dirce Shizuko Fujisawa(1).
}

\begin{abstract}
Introduction: Postural control is the interaction between the systems, the central nervous and the musculoskeletal, based on information from the system somatosensory, vestibular and visual, to capture and control the body segments, alignments and movements. The studies reporting that data the anthropometric influence on the postural control, among the findings arte the characteristics of the feet, such as foot size and type. The gold standard instrument of evaluation of postural control is the force platform (PF). Objective: To determine the correlation between postural control and the length of the feet in students with eight years old. Method: Cross-sectional Study with convenience sample with students enrolled in schools of the city of Londrina/PR. The collection consisted of personal identification, anthropometric data, and assessment of postural control on the FP. The body mass was obtained by means of weighing on a digital scale, stature was measured using a tape measure and the length of the feet was measured by means of a tape measure positioned in the calcaneus until the end of the first finger. The evaluation of the postural control was in unipodal support, 30 seconds permanence, three attempts with one-minute interval between them. Results: We evaluated 346 school, 180 (52\%) female and 166 (48\%) were male. Leg preference was to the right on 224 (64.7\%), and the median length of feet was of $0.21(0.21 / 0.22)(\mathrm{m})$. The children presented themselves in the position one-leg area of the COP $13.41 \pm 6.77\left(\mathrm{~cm}^{2}\right)$. The correlation of COP with size of the feet has been identified, but considered to be low ( $p=0.000$ and $r=0.224)$. Conclusion: The correlation between the postural control and the length of the feet was low, since the complex mechanism in which other intrinsic factors and extrinsic are also able to influence it.
\end{abstract}

Key-words: Child. Postural Balance. Anthropometry.

\section{INTRODUCTION}

Postural control has been studied comprehensively because is efficient and fundamental for the performance of most daily tasks. Postural control is the interaction between the central nervous system (CNS) and the musculoskeletal system, based on information received from the somatosensory, vestibular and visual system, in order to capture positions and variable movements of the body. ${ }^{(1-4)}$

In the first year of life, the child begins to gain mobility and, afterwards, to ensure the execution of its own movements against gravity, in which will be improved throughout the first decade of life. ${ }^{(5,6)}$ Around eight to twelve years, occur the maturation of systems related to posture and balance. ${ }^{(7)}$ Children in age of seven years old have reached oscillating values similar to adults in tests on the force platform with eyes open. ${ }^{(8)}$

The anthropometric variables influence the postural control, among them are the characteristics of the feet. ${ }^{(9)}$ The foot is a proprioceptive system together with mechanoreceptors in large quantities in the soles of the feet, which are able to identify minimum pressures. ${ }^{(10)}$ The CNS has the foot somatosensory information graduating force, position, speed of the body and gravity orientation on surfaces and contact the external environment. ${ }^{(11,12)}$ The gold standard instrument for postural control assessment is the force platform (FP). ${ }^{(13,14)}$

Since the study on postural control in childhood is extremely important, the aim is to verify the correlation between feet size and postural control of children in the school age. The hypothesis is that the greater the area of plantar support of a child, the better their postural control, since the number of mechanoreceptors in contact with the surface will increase, therefore a negative correlation is expected. Better understanding of foot length as an influence factor for postural control will contribute to both assessment and treatment of children with impaired balance.

\section{METHODS}

\section{Sample}

A cross-sectional study was carried out with a convenience sample, and 8-year-old children enrolled in the Municipal School, Londrina/PR/BR, were evaluated. The study included healthy children with typical development, authorized by their parents or guardians and who agreed to participate in data collection. We excluded children who were unable to remain in the orthostatic or ambulatory position, those 
with orthopedic, neurological and rheumatic disorders and sensory deficits, history of neuromuscular diseases or previous traumatic orthopedic surgeries, with acute or chronic diseases and congenital malformations, complaints of dizziness, vertigo and those which use continuous medications.

The research was authorized by the Municipal Department of Education and approved by the Committee of Ethics in Research involving Human Beings of the State University of Londrina (No. 761.965).

\section{Procedure}

Data collection was started by collecting the child identification data: name, birth date, genre and schooling (school, series and period). The body mass was obtained by weighing the Marte scale model LC 200, year 2010, with a maximum capacity of $200 \mathrm{~kg}$ and a minimum of $1000 \mathrm{~g}$. The children were weighed without shoes or socks, wearing only the school uniform, being oriented to remain in orthostatism, limbs along the body and looking forward. The stature was measured using a tape measure of $150 \mathrm{~cm}$, with marking of $0.1 \mathrm{~cm}$. The children were oriented to remain erect, knees in extension, feet together, arms loose and along the body, with the ankles, gluteal region and shoulders in contact with the wall. The feet length was measured by a metric tape positioned from the calcaneus to the end of the first toe.

The postural control of the children was evaluated by means of FP, which consists of two rigid rectangular surfaces, one upper and one lower, interconnected by four load cells, which measure the vertical component of the ground reaction force. From the ground reaction force, the EMG System do Brasil $^{\circledR}$ software performs the center of pressure calculation (COP) and the variables related to their space-temporal variation. In FP the child was instructed to remain in unipedal stance, choosing the lower limb, the trunk in an upright position with the upper limbs at the side of the body, while the contralateral lower limb remained with the hip in neutral position and the knee flexed at $90^{\circ}$. On the wall at the front it was a 2 meters point distant, arranged at the height of the eyes, in which the participant was directed to direct his gaze. The remaining time was standardized in 30 seconds and 3 trials, with a one minute interval, in the analysis, the mean of the 3 trials was used.

\section{Statistical analysis}

The data collected were inserted into Microsoft Excel and analyzed using the SPSS (Version 20.0). The Shapiro-Wilk test was used to verify the data normality. Data were presented in relative and absolute frequency, mean and standard deviation, medians and quartiles (25\%/75\%). The Spearman correlation coefficient was used between postural control and size of the feet. Statistical significance was determined at $p<0.05$.

\section{RESULTS}

The study included 346 (100\%) children, 180 (52\%) females and 166 males (48\%). Anthropometric data are described below (TABLE 1). The unipedal preference for the FP test was 224 children (64.7\%) for the right lower limb and 122 (35.3\%) for the left.

The correlation between COP and size of the feet was positive, i.e., as size of the feet increases the COP area also increases, but was weak ( $p=0.000 r=0.224)$.

\section{DISCUSSION}

In our study, the COP area was $13.41 \pm 6.77 \mathrm{~cm}^{2}$, since the values of literature were $11.00 \pm 4.31 \mathrm{~cm}^{2}$, in children nine years old $(n=17)$ and $19.73 \pm 13.68 \mathrm{~cm}^{2}$ in participants seven years of age $(n=40) .^{(16-17)}$ Although COP was between the values described in these studies, the area was different, this fact may have occurred due to the difference in sample size or the age group have not been as the same evaluated in this study. The age range defined for this study indicates seven-year as the transition age for the maturation of postural control abilities, such as reflex and proprioceptive anticipatory responses. ${ }^{(18)}$ Children aged seven years reach COP oscillation values similar to those of adults in tests with eyes open. ${ }^{(19)}$

Regarding anthropometric measures, this study considered the body mass $(\mathrm{kg})$, height $(\mathrm{m})$ and feet length $(\mathrm{cm})$ of the evaluated students. The feet are part of a proprioceptive set with mechanoreceptors which identify pressures on the soles of the feet and measure the strength and position of the body, identifying and guiding the movements. ${ }^{(10-12)}$ In the absence of information from cutaneous receptors the movement is impaired. ${ }^{(20)}$ Thus, it may be predicted that the larger plantar support area, ie, the greater the length of the foot of a child, the better is the balance, since the amount of mechanoreceptors in contact with the surface is larger. The result of this study showed that the greater the length of the feet, the child presented a COP larger area, not confirming the hypothesis. Other studies, when evaluating the anthropometric variables and the balance, showed that the characteristics of the feet interfere in anteroposterior oscillations and that the height and length of the feet interfere in mid-lateral oscillations. ${ }^{(21)}$

The correlation of COP with the size of the feet in our study was positive and weak ( $p=0.000 r=0.224$ ), and size of the feet had little interference on postural control. Some reasons may

Table 1 - Anthropometric measurements and static postural control.

\begin{tabular}{lccc}
\hline & \multicolumn{3}{c}{ Percentile } \\
\cline { 2 - 4 } & $\mathbf{2 5 \%}$ & Median & $\mathbf{7 5 \%}$ \\
\hline Body mass $(\mathrm{Kg})$ & 26.87 & 30.20 & 36.30 \\
Height $(\mathrm{m})$ & 1.29 & 1.33 & 1.37 \\
Lenght of feet $(\mathrm{cm})$ & 0.21 & 0.21 & 0.22 \\
COP area $\left(\mathrm{cm}^{2}\right)$ & 9.96 & 13.41 & 18.47 \\
\hline
\end{tabular}


have influenced, such as, age restricted to eight years old, performance of other anthropometric and postural factors (stature, BMI, foot types), CNS maturation and experiences of other systems acquired differently by each child until the evaluated age. Although seven years old is defined as the transition age to the maturation of postural control, this age still does not show a mature pattern when compared to adults, and at the age of eight to twelve years old as the final stage of maturation. ${ }^{\text {(22.23) }}$

Other anthropometric measures also interfere with postural control. A study used the height of 45 subjects to assess the influence on balance in three groups, it was concluded that the displacement of the ankle and gastrocnemius response increased as height increases. ${ }^{(24)}$ The cavus foot was observed as a type of feet with significantly higher COP than other two groups (rectus or planus) in a group of 30 evaluated. (25) Among 20 patients evaluated by body mass index (BMI), it was found that people who are overweight and obesity showed a worse balance, regardless of gender. ${ }^{(26)}$

The maturation process of CNS occurs differently in each child, according to the experiences. Sensory information guides and adjusts the body in relation to the external environment through experiences acquired during growth and development, developing strategies which will be perform by the musculoskeletal system. ${ }^{(27)}$ When the sensory environment changes, it readjusts itself for the body to suffer the smallest possible conflicts. ${ }^{(28)}$ Thus, it may be said that different environments induce various sensory adaptation in each child, providing particular experiences in each child, which probably had maturation times of postural control different among each other.

The 346 evaluated children in this study was significantly higher than those found in the literature, which did not exceed the sample of 100 individuals; however, the age group was restricted, it is suggested that other studies be performed with broader ranges in order to capture more evolved patterns of postural control in schoolchildren.

The study of postural control in 8-year-old schoolchildren is valuable, since this age is considered by many authors as the height of postural control development, balance, maintenance of posture and accomplishment of activities and prophylactic measures and treatment might avoid harmful alterations.

\section{CONCLUSION}

The correlation between postural control and foot length was positive and weak, since it is a complex mechanism in which other intrinsic factors (vision, hearing, obesity, etc.) and extrinsic (school backpacks, shoes, etc.) are also capable of influence it.

\section{ACKNOWLEDGMENTS}

Capes for the acquisition of power platform and to the Social Demand Program, the PIBIC/CNPq, the Araucária Foundation, the Municipal Secretary of Education of Londrina-PR, the directors and teachers of the municipal schools, parents and students.

\section{AUTHOR'S CONTRIBUTION}

DFEA: Author; JCJN: Co-advisor; DSF: Advisor.

\section{CONFLICTS OF INTEREST}

The author(s) declare that they have no competing interests.

\section{REFERENCES}

1. Massion J, Woollacott MH. Posture and equilibrium. In: Bronstein AM, Brandt T, Woollacott MH. Clinical disorders of balance posture and gait. London: Arnold, 1996.

2. Isableau B, Ohlmann T, Cremieux J, Amblard B. Selection of spatial frame of reference and postural control variability. Exp Brain Res, 1997;114:(3)5849.

3. Latash ML. Neurophysiological basis of human movement. Champaign: Human Kinetics, 1997.

4. Guerraz M, Thilo KV, Bronstein AM, Gresty MA. Influence of action and expectation on visual control of posture. Brain Res Cogn Brain Res. 2000; 11:(2)259-66.

5. Adolph KE, Bertenthal BI, Boker SM, Goldfield EC, Gibson EJ. Learning in the development of infant locomotion. Monogr Soc Res Child Dev. Chicago, 1997; 62:(2)1-140.

6. Adolph KE, Berger SA. Motor development. In: DAMON, W.; LERNER, R. (Eds.). Handbook of child psychology: cognition, perception, and language. 6th. ed. New York: Wiley, p. 161-213.

7. Gallahue, DL, Ozmun JC. Compreendendo o desenvolvimento motor: bebes, crianças, adolescentes e adultos. São Paulo: Editora Phorte, 2005.

8. Hsu YS, Kuan C C, Young YH. Assessing the development of balance function in children using stabilometry. Int J Pediatr Otorhinolaryngol, 2009; 75:(5)737- 740.

9. Alonso AC, Mochizuki L, Monteiro CBM, Santos S, Luna NMS, Brech $\mathrm{GC}$, et al. Fatores antropométricos que interferem no equilíbrio postural. Braz J Biomec, 2012; 13:(25).

10. Bricot B. Posturologia. 2a ed. São Paulo: Ícone, 2001.

11. Horak FB, Macpherson JM. Postural orientation and equilibrium. In: Rowell LB, Shepard JT, eds. Handbook of physiology: Section 12, Exercise Regulation and Interation of Multiple Systems. New York: Oxford Univertisty, 1996, 255-92.

12. Castro EM. Developing an "anchor" system to enhance postural control. Motriz, 2004; 8:(11)339-58.

13. Mancine M, Horak FB. The relevance of clinical balance assessment tools to differentiate balance deficits. Eur J Phys Rehabil Med. 2010;46:(2)23948.

14. Terekhov Y. Stabilometry as a diagnostic tool in clinical medicine. Can Med Assoc J. 1976;115:(7)63-633.

15. Winter DA. Motor mechanism of balance during quiet standing. J electromyogr kinesiol. 2003;13:(1)49-56.

16. Moraes AG, David AC, Castro OG, Marques BL, Carolino MS, Maia EM. Comparação do equilíbrio postural unipodal entre crianças e adultos. São Paulo: Rev Bras Educ Fís Esporte, 2014;28:(4)571-77.

17. Castro OG, David AG. Deslocamento do centro de pressão nas posições bipodal e unipodal em crianças. Brasília: Universidade de Brasília, 2013.

18. Nolan L, Grigorenko A, Thorstensson A. Balance control: sex and age differences in 9- to 16-year-olds. Dev Med Child Neurol, 2005;47:(7) 449-454.

19. Hsu YS, Kuan C C, Young YH. Assessing the development of balance function in children using stabilometry. Int J Pediatr Otorhinolaryngol, 2009;73:(5)737-740.

20. Rothwell, J. Control of human voluntary movement. 2. ed. London: Chapmann \& Hall, 1994. 
21. Kejonen, $\mathrm{P}$, Kauranen $\mathrm{K}$, Vanharanta $\mathrm{H}$. The relationship between anthopometric factors and body-balancing movements in postural balance. Arch Phys Med Rehabil, 2003; 84:(1)17-22.

22. Riach CL, Hayes KC. Maturation of postural sway in young children. Dev Med Child Neurol. 1987;29:(5)650-8.

23. Gallahue, DL, Ozmun JC. Compreendendo o desenvolvimento motor: bebes, crianças, adolescentes e adultos. São Paulo: Editora Phorte, 2005.

24. Berger, W, Trippel M, Discher M, Dietz V. Influence of subjects' height on the stabilization of posture. Acta Otolaryngol, 1992;112:(1)22-30.
25. Hertel J, Gay MR, Denegar CR. Differences in postural control during single-leg stance among healthy individuals with different foot types. J Athl Train, 2002;37:(2)129- 132.

26. Singh D, Park W, Levy MS, Jung ES. The effects of obesity and standing time on postural sway during prolonged quiet standing. Ergonomics, 2009;52:(8)977-86.

27. Bacsi AM, Colebatch JG. Evidence for reflex and perceptual vestibular contributions to postural control. Exp Brain Res, 2005;160:(1)22-8.

28. Mochizuki L, Amadio AC. As informações sensoriais para o controle postural. Fisioter Mov, 2006;19:(2)11-8. 